\title{
CCL20/CCR6 expression profile in pancreatic cancer
}

\author{
Claudia Rubie*+1, Vilma Oliveira Frick ${ }^{+1}$, Pirus Ghadjar ${ }^{3}$, Mathias Wagner ${ }^{2}$, Henner Grimm¹, Benjamin Vicinus ${ }^{1}$, \\ Christoph Justinger ${ }^{1}$, Stefan Graeber ${ }^{4}$ and Martin K Schilling
}

\begin{abstract}
Background: CCL20 and its receptor CCR6 have been shown to play a role in the onset, development and metastatic spread of various gastrointestinal malignancies. In this study, the expression profile and clinical significance of the CCL20/CCR6 system in distinct benign, pre-malignant and malignant pancreatic tissues was investigated.

Methods: Using RealTime-PCR, enzyme-linked immunosorbent assay (ELISA), Western Blot and immunohistochemistry, we have analyzed the expression profile of CCL20/CCR6 in resection specimens from patients with chronic pancreatitis (CP) $(n=22)$, pancreatic cystadenoma (PA) $(n=11)$ and pancreatic carcinoma $(P C A)(n=25)$ as well as in the respective matched normal pancreatic tissues.

Results: CCL20 mRNA and protein was weakly expressed in normal pancreatic tissues and CP and PA specimens but significantly up-regulated in PCA (8-fold) as compared to the matched normal tissue ( $P<0.05)$. Moreover, CCL20 mRNA and protein expression was significantly associated with advanced T-category in patients with $P C A(P<0.05)$. CCR6 mRNA showed a significant up-regulation in all three disease entities as compared to normal tissues $(P<0.05$, respectively).

Conclusion: CCL20 and CCR6 were significantly up-regulated in PCA as compared to the normal pancreatic tissue and CCL20 was significantly associated with advanced T-category in PCA patients. This suggests that CCL20 and CCR6 play a role in the development and progression of PCA and may constitute potential targets for novel treatment strategies.
\end{abstract}

\section{Background}

Pancreatic adenocarcinoma (PCA) is characterized by its late presentation, early and aggressive local and distant metastasis, unresponsiveness to most treatment options and an extremely dismal prognosis $[1,2]$. Despite of curative surgery the life expectancy of PCA patients is very poor and the 5-year overall survival is less than $20 \%$ [3]. Histologically, PCA is characterized by an intense inflammatory reaction and cancer cells shaped like duct-like glandular elements surrounded by fibrosis. As the mortality rate of PCA is virtually equal to its incidence, new strategies and therapies are urgently required to improve the clinical outcome of this disease.

The potential mechanisms and pathways accounting for the aggressive biology of PCA have been intensely

\footnotetext{
* Correspondence: claudia.rubie@uks.eu

1 Dept. of General -, Visceral-, Vascular - and Paediatric Surgery, University of the Saarland, 66421 Homburg/Saar, Germany

+ Contributed equally

Full list of author information is available at the end of the article
}

investigated pointing to the expression of various proangiogenic factors, molecular changes in oncogenes and tumor suppressor genes as well as abnormalities in growth factors and cytokines [4-7]. Currently, accumulating data suggest that chemokines and their receptors play a role in the tumor biology of PCA [8-11] and various other types of cancer $[12,13]$. A limited number of studies have outlined a role of CCL20 (also termed Macrophage Inflammatory Protein-3 $\alpha$, Larc, or Exodus) in PCA development and progression [14-16]. CCL20 belongs to the family of CC-chemokines but shares only less than $30 \%$ identity with other members of this chemokine family. Expression of CCL20 has been reported in macrophages, eosinophils and dendritic cells and it is well established that CCL20 contributes to inflammatory cell recruitment [17]. Only the G-protein coupled 7-transmembrane receptor CCR6, which is also expressed in human dendritic cells, shows a strong interaction with CCL20 [18]. Thus, CCL20 selectively signals through CCR6. Expres- 
sion of CCL20 has been confirmed in various human cancer entities, such as leukaemia, lymphoma, melanoma, hepatocellular carcinoma, prostate cancer, colorectal adenocarcinoma and lung and oral squamous cell carcinoma [19-22]. Moreover, expression of the CCL20/CCR6 system has been reported in PCA tissues and pancreatic cancer cell lines. Stimulation of the CCR6 bearing PCA cells with CCL20 led to an increased proliferation, migration and invasion and it was postulated that CCL20 may act via autocrine and paracrine mechanisms to contribute to the pathobiology of human PCA [14-16]. Recent studies demonstrated that CCL20 may promote pancreatic tumor cell migration and invasion through the up-regulation of matrix metalloproteinase production [16].

Here, we comparatively investigated the expression profile and clinical significance of the CCL20/CCR6 system in PCA as well as in chronic pancreatitis (CP) and pancreatic cystadenoma (PA) which represent pre-malignant conditions often preceding the development of PCA. Essentially, we report significant CCL20/CCR6 upregulation in PCA tissues compared to matched normal pancreatic tissues. In addition, we detected a significant correlation of CCL20 expression with advanced T-category in PCA patients suggesting an involvement of CCL20/CCR6 in the development and progression of PCA.

\section{Methods \\ Materials}

Surgical specimens and corresponding normal tissue from the same samples were collected from patients who underwent surgical resection at our department between 2002 and 2008.

Informed written consent for tissue procurement was obtained from all patients and the study was approved by the local ethics commission of the Ärztekammer des Saarlandes.

Fifty-eight patients were enclosed in the study, consisting of patients with primary ductal PCA $(\mathrm{n}=25), \mathrm{CP}(\mathrm{n}=$ $22)$ and PA $(n=11)$. In every patient sample the corresponding non-affected normal pancreatic tissue was also analyzed, thus the total sample size was 116 . Of the 25 patients with cancer one cancer was classified as pT1, six as pT2, fifteen as pT3 and three as pT4, with positive nodal involvement in 17 cases, according to the UICC TNM classification [23]. No patient had received any kind of neoadjuvant therapy prior to resection. The clinical data and patient characteristics for the different premalignant and malignant entities were obtained from a prospective database and are summarized in table 1 and table 2.

\section{Tissue preparation}

Tissue specimens were collected immediately after surgical resection, snap frozen in liquid nitrogen and then stored at $-80^{\circ} \mathrm{C}$ until they were processed under nucleic acid sterile conditions for protein extraction. For corresponding normal tissue we used adjacent non-affected tissue from the same resected specimens. All tissues obtained were reviewed by an experienced pathologist and examined for the presence of tumor cells. As minimum criteria for usefulness for our study, we only used tumor tissues in which tumor cells constituted at least > $70 \%$ of the tumor biopsy.

\section{Single-strand CDNA synthesis}

Total RNA was isolated using RNeasy columns from Qiagen (Hilden, Germany) according to the manufacturer's instructions. RNA integrity was confirmed spectrophotometrically and by electrophoresis on $1 \%$ agarose gels. For cDNA synthesis $5 \mu \mathrm{g}$ of each patient total RNA sample were reverse-transcribed in a final reaction volume of 50 $\mu \mathrm{L}$ containing $1 \times$ TaqMan RT buffer, $2.5 \mu \mathrm{M} / \mathrm{L}$ random hexamers, $500 \mu \mathrm{M} / \mathrm{L}$ each dNTP, $5.5 \mathrm{mM} / \mathrm{L} \mathrm{MgCl}_{2}, 0.4 \mathrm{U} /$ $\mu \mathrm{l}$ RNase inhibitor, and 1.25 U/ $\mu \mathrm{L}$ Multiscribe RT. All RTPCR reagents were purchased from Applied Biosystems (Foster City, CA). The reaction conditions were $10 \mathrm{~min}$ at $25^{\circ} \mathrm{C}, 30 \mathrm{~min}$ at $48^{\circ} \mathrm{C}$, and $5 \mathrm{~min}$ at $95^{\circ} \mathrm{C}$.

\section{Real-time PCR}

All Q-RT PCR assays containing the primer and probe mix were purchased from Applied Biosystems, (Applied Biosystems, Foster City, CA) and utilized according to the manufacturer's instructions. PCR reactions were carried out using $10 \mu \mathrm{L} 2 \times$ Taqman PCR Universal Master Mix No AmpErase ${ }^{\circ} \mathrm{UNG}$ and $1 \mu \mathrm{L}$ gene assay (Applied Biosystems, Foster City, CA), $8 \mu \mathrm{L}$ Rnase-free water and $1 \mu \mathrm{L}$ cDNA template $(50 \mathrm{mg} / \mathrm{L})$. The theoretical basis of the qRT assays is described in detail elsewhere [24]. All reactions were run in duplicates along with no template controls and an additional reaction in which reverse transcriptase was omitted to assure absence of genomic DNA contamination in each RNA sample. For the signal detection, ABI Prism 7900 sequence detector was programmed to an initial step of $10 \mathrm{~min}$ at $95^{\circ} \mathrm{C}$, followed by 40 thermal cycles of $15 \mathrm{~s}$ at $95^{\circ} \mathrm{C}$ and $10 \mathrm{~min}$ at $60^{\circ} \mathrm{C}$ and the $\log$-linear phase of amplification was monitored to obtain $\mathrm{C}_{\mathrm{T}}$ values for each RNA sample.

Gene expression of all target genes was analyzed in relation to the levels of the slope matched housekeeping genes phosphomannomutase (PMM1) and cyclophilin C $(\mathrm{CycC})$ [25]. Analysis was performed using the delta CT method and samples were normalized to the control tissue sample. Hence, the normal tissue became the $1 \times$ sample, and all other quantities were expressed as an $n$ fold difference relative to this tissue.

\section{Isolation of total protein}

Protein lysates from frozen tissue were extracted with the radioimmunoprecipitation (RIPA) buffer containing 
Table 1: Clinical characteristics of patients with pre-malignant pancreatic diseases

\begin{tabular}{|c|c|c|}
\hline Characteristic & Pancreatic Cystadenoma $(n=11)$ & Chronic Pancreatitis $(\mathrm{n}=\mathbf{2 2})$ \\
\hline \multicolumn{3}{|l|}{ Gender } \\
\hline Male & 5 & 14 \\
\hline Female & 6 & 8 \\
\hline \multicolumn{3}{|l|}{ Age (years) } \\
\hline Median & 57.1 & 53.5 \\
\hline Range & $32-73$ & $39-71$ \\
\hline \multicolumn{3}{|l|}{ Diabetes mellitus } \\
\hline Positive & 2 & 5 \\
\hline Negative & 9 & 17 \\
\hline \multicolumn{3}{|l|}{ Nicotine abuse } \\
\hline Positive & 3 & 13 \\
\hline Negative & 8 & 9 \\
\hline \multicolumn{3}{|l|}{ Alcohol abuse } \\
\hline Positive & 1 & 8 \\
\hline Negative & 10 & 14 \\
\hline
\end{tabular}

Complete, a protease inhibitor cocktail (Roche, Penzberg, Germany). Total protein quantification was performed using the Pierce BCA protein assay reagent kit (Pierce, Rockford, Ill., USA).

\section{Sandwich-Type Enzyme-Linked Immunosorbent Assay}

The chemokine protein levels in the different tissue lysates were determined by sandwich-type enzymelinked immunosorbent assays (ELISA) according to the manufacturer's instructions. Samples were assayed in duplicate with all values calculated as the mean of the two measurements. CCL20 levels were assayed using a validated commercial ELISA (Duo Set R\&D Systems, DY360, Minneapolis, Minn., USA). The absorbance was read at $450 \mathrm{~nm}$ in a 96-well microtiter plate reader. The chemokine concentration from each tissue lysate was normalized to the total protein content of each sample.

\section{Immunohistochemistry}

Operative specimens were routinely fixed in formalin and subsequently embedded in paraffin. Before staining, 4$\mu \mathrm{m}$ thick paraffin-embedded tissue section were mounted on Superfrost Plus slides, deparaffinized and rehydrated in graded ethanol to deionized water. The sections were microwaved with an antigen retrieval solution (Target Retrieval, Dakocytomation, Carpinteria, CA, USA) and after blocking of endogenous peroxidase activity with $3 \%$ hydrogen peroxide, the sections were further blocked for $30 \mathrm{~min}$ at room temperature with normal rabbit serum. Overnight incubation at $4^{\circ} \mathrm{C}$ with primary goat polyclonal anti-human CCL20 antibody $(15 \mu \mathrm{g} / \mathrm{ml}$, AF254, R\&D Systems, Minneapolis, Minn., USA) was fol- lowed by incubation of secondary biotinylated rabbit anti-goat IgG antibody and the avidin-biotin-peroxidase reaction (Vectastain ABC ELITE Kit, Vector Laboratories, Burlingame, CA, USA). After colour reaction with aminoethylcarbazide solution (Merck, Darmstadt, Germany), tissues were counterstained with haematoxylin. Negative controls were performed in all cases omitting primary antibody.

\section{Western Blot Analysis}

Total protein $(25 \mu \mathrm{g} / \mathrm{lane})$ was separated by SDS-PAGE using a $10 \%$ gel and blotted onto nitrocellulose membranes (Hybond ECL, Amersham Biosciences, Piscataway, NJ, USA). Membranes were blocked by incubation in Tris-buffered saline (TBS) containing 5\% nonfat dry milk and $0.1 \%$ Tween 20 for $2 \mathrm{~h}$ at room temperature and then incubated overnight at $4{ }^{\circ} \mathrm{C}$ with goat anti-human CCR6 antibody (diluted 1:500, C2099-70B, Biomol, Hamburg, Germany). Blots were then washed and incubated at room temperature for $1 \mathrm{~h}$ with donkey anti-goat HRP antibody (diluted 1:5000, sc-2056, Santa Cruz Biotechnology, Santa Cruz, CA USA). Bands were visualized by ECL Western blotting analysis systems (Amersham Biosciences, Piscataway, NJ, USA). The human cell lysate HL-60 (sc-2209, Santa Cruz Biotechnology, Santa Cruz, CA, USA) served as positive control. Quantification of figure four has been performed on three independent samples using image J software.

\section{Calculations and Statistical Analysis}

All chemokine concentrations are presented as mean and SEM (standard of the mean). All statistical calculations 
Table 2: Clinical characteristics of patients with pancreatic cancer

\begin{tabular}{|c|c|}
\hline Characteristic & $\begin{array}{l}\text { Pancreatic Cancer } \\
(\mathbf{n}=\mathbf{2 5})\end{array}$ \\
\hline \multicolumn{2}{|l|}{ Gender } \\
\hline Male & 17 \\
\hline Female & 8 \\
\hline \multicolumn{2}{|l|}{ Age (years) } \\
\hline Median & 64.7 \\
\hline Range & $42-79$ \\
\hline \multicolumn{2}{|c|}{ Diabetes mellitus } \\
\hline Positive & 16 \\
\hline Negative & 9 \\
\hline \multicolumn{2}{|l|}{ Nicotine abuse } \\
\hline Positive & 5 \\
\hline Negative & 20 \\
\hline \multicolumn{2}{|l|}{ Alcohol abuse } \\
\hline Positive & 3 \\
\hline Negative & 22 \\
\hline \multicolumn{2}{|c|}{ Largest tumor diamter $(\mathrm{cm})$} \\
\hline Median & 3.5 \\
\hline Range & $1.5-4.7$ \\
\hline \multicolumn{2}{|c|}{ Tumor (T)-category } \\
\hline pT1 & 1 \\
\hline pT2 & 6 \\
\hline pT3 & 15 \\
\hline pT4 & 3 \\
\hline \multicolumn{2}{|c|}{ Lymph node metastasis } \\
\hline Positive & 17 \\
\hline Negative & 8 \\
\hline Grade & 1 \\
\hline G1 & 6 \\
\hline G2 & 18 \\
\hline \multicolumn{2}{|l|}{ G3 } \\
\hline \multicolumn{2}{|c|}{ Vascular permeation } \\
\hline Positive & 6 \\
\hline Negative & 19 \\
\hline
\end{tabular}

were done with the MedCalc (MedCalc software, Mariakerke, Belgium) software package [26]. The parametric Student's t-test was applied, if normal distribution was given, otherwise, the Wilcoxon's rank sum test was used. T-category was dichotomized (pT1 - pT2 vs. pT3 - pT4). P-values $<0.05$ at a two-sided level of $\alpha<0.05$ were considered significant.

\section{Results}

CCL20/CCR6 mRNA expression in benign, pre-malignant and malignant pancreatic tissues

CCL20 mRNA was weakly expressed in the normal pancreatic tissue as well as in PA and CP specimens. In PCA specimens CCL20 mRNA showed a significant 8-fold upregulation as compared to the matched normal tissues ( $\mathrm{P}$ $<0.05$ ) (Figure 1A). As shown in Figure 1B CCR6 mRNA expression was significantly up-regulated in all 3 disease entities $(\mathrm{P}<0.05$, respectively) as compared to the normal tissue, with PCA and PA specimens showing a 4-fold and $\mathrm{CP}$ tissues showing a 3-fold up-regulation, respectively.

\section{CCL20/CCR6 protein expression in benign, pre-malignant} and malignant pancreatic tissues

CCL20 protein was weakly expressed in normal pancreatic tissue and in PA and CP specimens. In PCA the CCL20 protein expression showed a significant 3-fold up-

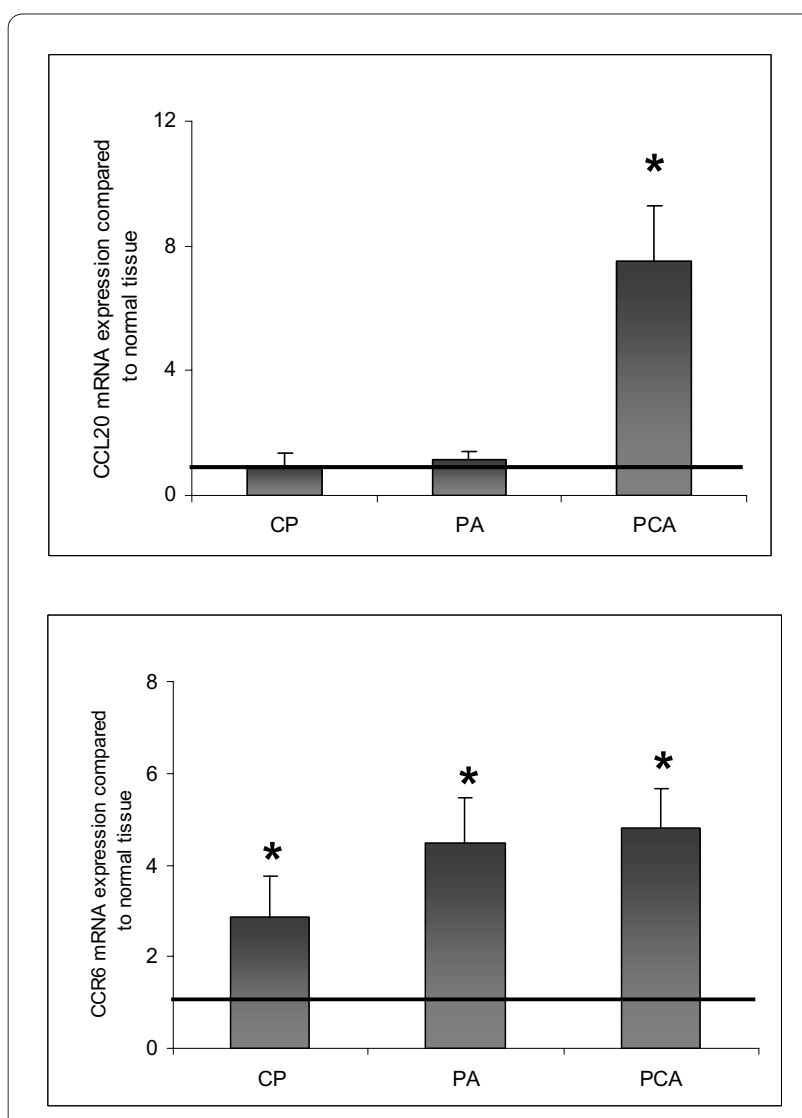

Figure 1 CCL20/CCR6 mRNA expression in pancreatic diseases. Gene expression of [A] CCL20 and [B] CCR6 in chronic pancreatitis (CP, $n=22)$, pancreatic cystadenomas ( $P A, n=11)$, pancreatic carcinoma (PCA, $n=25$ ) compared to matched normal pancreatic tissues as determined by Q-RT-PCR. Q-RT-PCR data are expressed as mean +/- SEM, ${ }^{*} P<0.05$. Fold increase above 1 indicates CCL20/CCR6 up-regulation compared to normal tissues. 
regulation compared to the matched normal pancreatic tissues $(\mathrm{P}<0.05)$ (Figure 2A).

As assessed by western blot analysis CCR6 protein expression was detectable in all pancreatic disease entities under investigation, namely in CP, PA and PCA tisssue specimens as shown for representative patients in Figure 2B. However, band intensity was significantly higher in the diseased tissues $(\mathrm{P}<0.05)$ and showed the highest value in PCA tissues (Figure $2 \mathrm{~B}$ ).

Using immunohistochemistry CP, PA and PCA specimens along with the corresponding normal tissues were evaluated for CCL20 expression (Figure 3). CCL20 signals were detected in all CP, PA and PCA specimens under investigation. In normal tissues, CCL20 staining was primarily found in pancreatic islet cells and rather sporadically in epithelial cells of pancreatic ducts as

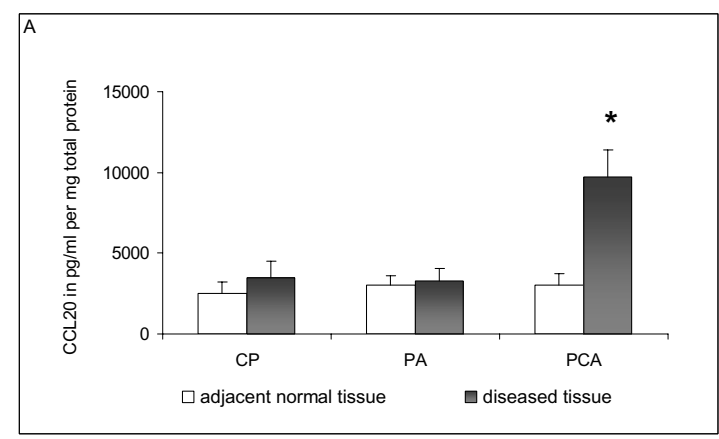

B
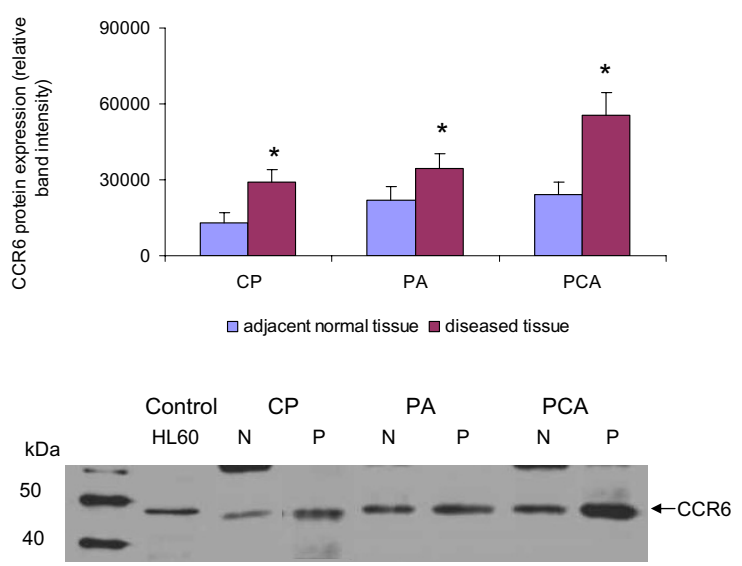

Figure 2 CCL20/CCR6 protein expression in pancreatic diseases [A] CCL20 protein concentrations (pg/ml pro $\mathrm{mg}$ total protein) in chronic pancreatitis ( $C P, n=22)$, pancreatic cystadenomas $(P A, n=11)$, pancreatic carcinoma (PCA, $n=25)$ compared to the matched normal pancreatic tissue levels (mean \pm SEM), ${ }^{*} p<0.05$. [B] Expression of chemokine receptor CCR6 in CP, PA and PCA as determined by Western blot analysis. Total cell lysates of tumor tissues of representative patients of each disease entity were immunoblotted with antibodies specifically recognizing chemokine receptor CCR6. Acute leukemia cell line HL60 served as a positive control for the detection of CCR6. Quantification has been performed using image J software ${ }^{*} p<0.05$. shown in Figure 3A and 3B. In CP tissues immunoreactive CCL20 signals were detected primarily in acinar parenchyma deformed by necrosis and sporadically in some epithelial cells of pancreatic ducts (Figure 3C). Likewise, CCL20 staining was found in epithelial cells of the characteristic net-like structures of PA tissues (Figure 3D). In PCA tissues CCL20 immunoreactivity was detected in the cytoplasms of ductal epithelial cancer cells (Figure 3E). Moreover, CCL20 signals were detected in infiltrates of perineural sheaths as shown in Figure 3F.

\section{T-Category dependent CCL20 expression in PCA}

CCL20/CCR6 mRNA and protein expressions in PCA were compared to several clinicopathological factors such as TNM stages, age, lymphatic and vascular invasion or pre-existing conditions like cirrhosis or fibrosis.

Clinical validation of CCR6 expression showed no significant association with any of the clinicopathological factors tested. However, CCL20 mRNA and protein expressions in PCA patients were significantly associated with advanced T-category $(\mathrm{p}<0.05)$ (Figure 4$)$.

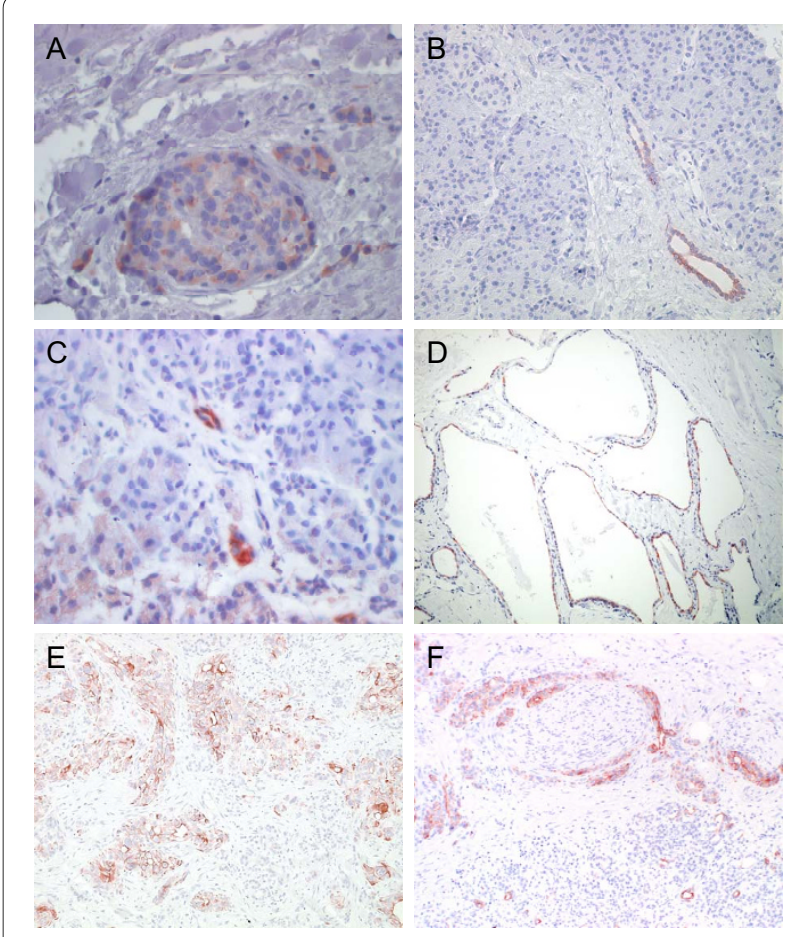

Figure 3 Results of anti-CCL20 immunohistochemistry in normal and diseased pancreatic tissues. Representative example of CCL2O expression in $[A, B]$ pancreatic islet cells and epithelial cells of pancreatic ducts, [C] necrotic parenchyma and epithelial cells of pancreatic ducts in chronic pancreatitis tissues [D] epithelial cells of the characteristic net-like structures of pancreatic cystadenoma $[E, F]$ cytoplasms of ductal epithelial cancer cells and in infiltrates of perineural sheaths. Anti-CCL20 goat anti-human, 75 g/ml (MIP-3a; R\&D Systems; Minneapolis, MN, USA. Avidin Biotin Complex (ABC) Method. (original magnification: $\times 200$ and 400, respectively). 


\section{Discussion}

In order to evaluate the potential contribution of CCL20/ CCR6 in development and progression of PCA, we analyzed the mRNA and protein expression profiles of the CCL20/CCR6 system in patients with PCA as well as in patients with $\mathrm{PA}$ and $\mathrm{CP}$, which represent pre-malignant diseases which often precede the formation of pancreatic malignancies $[27,28]$. Originally, CCL20 and CCR6 were demonstrated to play a role in inflammatory responses $[29,30]$. Thus, CCL20 was presented as a potent chemoattractant for immature dendritic cells (DCs) and their precursors to sites of potential antigen-entry [31]. In PCA, co-expression of CCL20 and CCR6 was reported in PCA tissues and in cultured human PCA cell lines. It has been demonstrated by others that stimulation of CCR6 bearing PCA cells with CCL20 led to increased proliferation, migration and invasion [14-16].

In accordance with earlier studies [14] reporting a faint but distinct CCL20 transcript in northern blot analysis of normal human pancreatic tissues, we observed low CCL20 mRNA and protein expression levels in the nor-
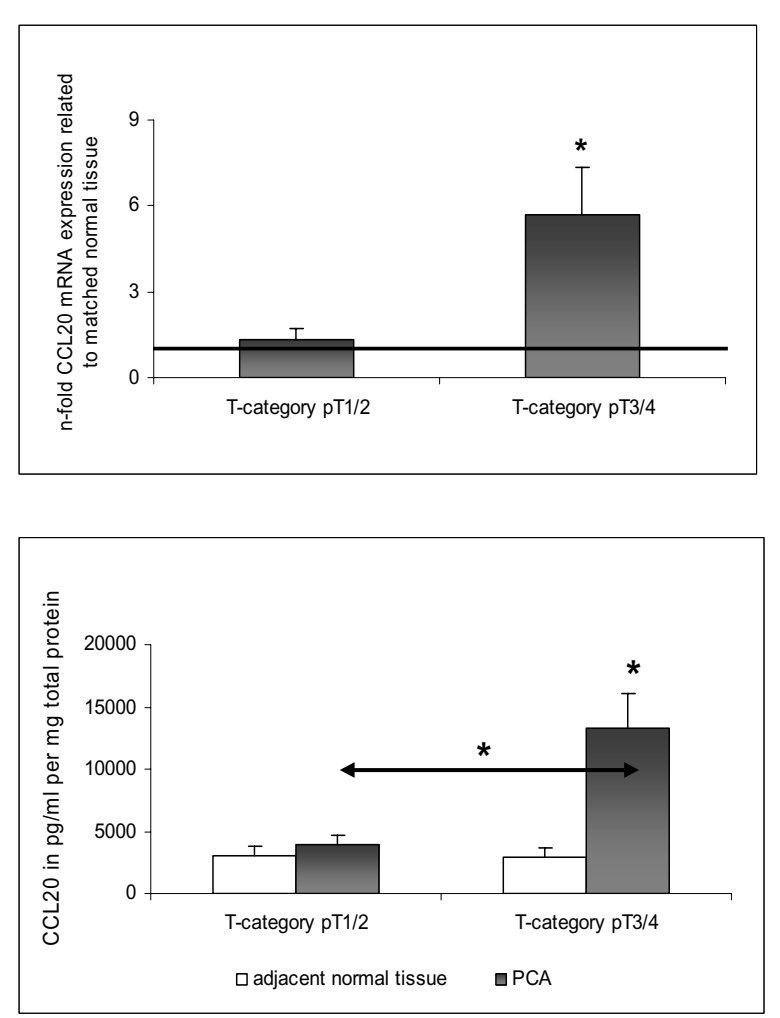

Figure 4 Expression of CCL20 in different tumor categories of PCA as determined by [A] Q-RT-PCR and [B] ELISA. mRNA and protein expression profiles of CCL20 ( $\mathrm{pg} / \mathrm{ml}$ pro $\mathrm{mg}$ total protein) were measured in PCA tissues and matched normal tissues in pT1 + pT2 ( $n$ =11) (A) and pT3 + pT4 $(n=14)(B)$, respectively. For Q-RT-PCR data fold increase above 1 indicates CCL20 up-regulation in PCA compared to normal tissues. All data are expressed as mean \pm SEM, ${ }^{*} \mathrm{p}<0.05$ mal pancreatic tissues analyzed. In PCA tissues the CCL20 transcript was detected in moderate to high levels $[14]$ and expression of the CCL20 protein was observed in cancer cells within the pancreatic tumor mass [16]. In accordance with these studies, we have observed a significant up-regulation of CCL20 mRNA and protein expression in PCA. Interestingly, comparing several clinicopathological factors to CCL20 mRNA and protein expression levels we found a significant correlation with advanced T-category pointing to a role for CCL20 and CCR6 in progression of PCA.

By immunohistochemistry we detected in CP immunoreactive CCL20 signals primarily in necrotic parenchyma and sporadically in some epithelial cells of pancreatic ducts, whereas in PA CCL20 staining was found in epithelial cells of the net-like structures of PA tissues and in pancreatic islet cells. In the PCA tissues we observed CCL20 immunoreactivity in the cytoplasms of ductal epithelial cancer cells, in infiltrates of perineural sheaths and also in tumor-associated macrophages. Others have reported that CCL20 could not be detected by immunohistochemistry in normal pancreatic tissue [16].

In $\mathrm{CP}$ and PA specimens, the CCL20 mRNA and protein expression was weak, comparable to matched normal tissues. CP has been suggested as an independent risk factor for the development of pancreatic cancer [28,32]. However, the risk of developing PCA in CP is also related to other factors such as age, the progression of molecular mutations, smoking, obesity and alcohol abuse [33,34]. Since the CCL20 expression profile in CP is entirely inconspicuous, a putative role of CCL20 and CCR6 in the process of progression from CP into PCA can be ruled out. Likewise, we observed an entirely inconspicuous CCL20 expression profile in PA, a pancreatic disease also suspected to precede the development of PCA. Thus, upregulation of CCL20 mRNA and protein is restricted to PCA tissues whereas CCL20 is not up-regulated by PA and CP. In contrast, CCR6 mRNA was not exclusively upregulated in PCA but also in PA and CP as compared to the matched normal tissues. Up-regulation of CCR6 expression has been observed in various cancer entities $[19,20,22,35]$. However, also in inflammatory diseases upregulation of CCR6 expression has been reported [36-38].

In summary, our findings suggest that CCR6 transcripts are up-regulated in PCA as well as in the premalignant pancreatic diseases $\mathrm{CP}$ and PA. In contrast, up-regulation of CCL20 mRNA and protein is restricted to PCA. Our results provide evidence that CCL20 expression is correlated with advanced T-category representing advanced PCA. On the basis of our findings and the current literature we conclude that CCL20 and CCR6 are involved in the development and progression of PCA and may constitute potential targets for novel treatment strategies. 


\section{Conclusions}

The results of this manuscript show that CCL20 and its corresponding receptor CCR6 are significantly up-regulated in patients with pancreatic cancer (PCA) and that CCL20 is significantly associated with advanced T-category in those patients. This suggests that CCL20 and CCR6 play a role in the development and progression of PCA. Thus, inhibition of CCR6 signalling or neutralization of CCL20 or inhibition of its production and activity may be useful in preventing further progression of the disease and may be a future basic treatment strategy in the management of PCA.

\section{Competing interests}

The authors declare that they have no competing interests.

\section{Authors' contributions}

All authors read and approved the final manuscript

All authors read and approved the final manuscript. CR is responsible for the design of the study, interpretation of the results and drafted the manuscript. VOF took part in all experimental elements, performed the ELISAs and participated in scientific discussions and interpretation of the results. MW examined the tissue sections for the presence of tumor cells, histopathologically confirmed all tissues under investigation, participated in scientific discussions and data interpretation. PG participated in scientific discussions and is responsible for the critical assessment and revision of the manuscript. HG collaborated in all the experimental elements. BV performed the western blots and contributed to scientific discussions and data interpretation. CJ provided clinical information and SG participated in the statistical analysis. MS is responsible for the provision of all the patient material and clinical information, participated in scientific discussions, data interpretation and revision of the manuscript.

\section{Acknowledgements}

We thank B. Kruse, C. Weber and B. Kopp for excellent technical assistance and HOMFOR (MW) for support with a digital camera (Olympus DP71).

\section{Author Details}

'Dept. of General -, Visceral-, Vascular - and Paediatric Surgery, University of the Saarland, 66421 Homburg/Saar, Germany, Institute of Pathology, University of the Saarland, 66421 Homburg/Saar, Germany, ${ }^{3}$ Department of Radiation Oncology, Inselspital, Bern University Hospital, and University of Bern, 3010 Bern, Switzerland and 4 Institute of Medical Biometrics, Epidemiology, and Medical Informatics (IMBEI) University of the Saarland, 66421 Homburg/Saar, Germany

Received: 5 October 2009 Accepted: 10 May 2010

Published: 10 May 2010

\section{References}

1. Jemal A, Siegel R, Ward E, Murray T, Xu J, Thun MJ: Cancer statitstics 2007. CA Cancer J Clin 2007, 57:43-66.

2. Lillemoe KD, Yeo CJ, Cameron JL: Pancreatic cancer: state-of-the-art care. CA Cancer J Clin 2000, 50:241-268.

3. Conlon KC, Klimstra DS, Brennan MF: Longterm survival after curative resection for pancreatic ductal adenocarcinoma: clinicopathologic analysis for 5-years survivors. Ann Surg 1996, 223:272-279.

4. Korc M: Role of growth factors in pancreatic cancer. Surg Oncol Clin N Am 1998, 7:25-41.

5. Friess $\mathrm{H}$, Kleeff J, Klockow $\mathrm{N}$, Ebert M, Malfertheiner P, Büchler MW: Molekulare Veränderungen bei Pankreas- und periampullären Karzinomen. Chir Gastroenterol 1999, 15:150-157.

6. Ebrahimi B, Tucker SL, Li D, Abbruzzese JL, Kurzrock R: Cytokines in pancreatic cancer - correlation with phenotypic characteristics and prognosis. Cancer 2004, 101:2727-2736.

7. Matsuo Y, Sawai H, Funahashi H, Takahashi H, Sakamoto M, Yamamoto M, Okada Y, Hayakawa T, Manabe T: Enhanced angiogenesis due to inflammatory cytokines from pancreatic cancer cell lines and relation to metastatic potential. Pancreas 2004, 28:344-352.
8. Marchesi F, Monti P, Leone BE, Zerbi A, Vecchi A, Piemonti L, Mantovani A, Allavena P: Increased survival, proliferation, and migration in metastatic human pancreatic tumor cells expressing functional CXCR4. Cancer Res 2004, 64:8420-8427.

9. Matsuo Y, Ochi N, Sawai H, Yasuda A, Takahashi H, Funahashi H, Takeyama H, Tong Z, Guha S: CXCL8/IL-8 and CXCL12/SDF-1alpha co-operatively promote invasiveness and angiogenesis in pancreatic cancer. Int $J$ Cancer 2009, 124:853-861.

10. Wente MN, Mayer C, Gaida MM, Michalski CW, Giese T, Bergmann F, Giese NA, Büchler MW, Friess H: CXCL14 expression and potential function in pancreatic cancer. Cancer Lett 2008, 259:209-217.

11. Wang Z, Ma Q, Liu Q, Yu H, Zhao L, Shen S, Yao J: Blockade of SDF-1/ CXCR4 signalling inhibits pancreatic cancer progression in vitro via inactivation of canonical Wnt pathway. Br J Cancer 2008, 99:1695-1703.

12. Kulbe H, Levinson NR, Balkwill F, Wilson JL: The chemokine network in cancer--much more than directing cell movement. Int J Dev Biol 2004, 48:489-496.

13. Balkwill F: Cancer and the chemokine network. Nat Rev Cancer 2004, 4:540-550.

14. Kleeff J, Kusama T, Rossi DL, Ishiwata T, Maruyama H, Friess H, Büchler MW, Zlotnik A, Korc M: Detection and localization of Mip-3alpha/LARC/ Exodus, a macrophage proinflammatory chemokine, and its CCR6 receptor in human pancreatic cancer. Int J Cancer 1999, 81:650-657.

15. Kimsey TF, Campbell AS, Albo D, Wilson M, Wang TN: Co-localization of macrophage inflammatory protein-3alpha (Mip-3alpha) and its receptor, CCR6, promotes pancreatic cancer cell invasion. Cancer J 2004, 10:374-380.

16. Campbell AS, Albo D, Kimsey TF, White SL, Wang TN: Macrophage inflammatory protein-3alpha promotes pancreatic cancer cell invasion. J Surg Res 2005, 123:96-101.

17. Caux C, Vanbervliet B, Massacrier C, Ait-Yahia S, Vaure C, Chemin K, DieuNosjean And MC, Vicari A: Regulation of dendritic cell recruitment by chemokines. Transplantation 2002, 73:7-11.

18. Greaves DR, Wang W, Dairaghi DJ, Dieu MC, Saint-Vis B, Franz-Bacon K Rossi D, Caux C, McClanahan T, Gordon S, Zlotnik A, Schall TJ: CCR6, a CC chemokine receptor that interacts with macrophage inflammatory protein 3alpha and is highly expressed in human dendritic cells. J Exp Med 1997, 186:837-844.

19. Ghadjar P, Coupland SE, Na IK, Noutsias M, Letsch A, Stroux A, Bauer S, Buhr HJ, Thiel E, Scheibenbogen C, Keilholz U: Chemokine receptor CCR6 expression level and liver metastases in colorectal cancer. J Clin Oncol 2006, 24:1910-1916.

20. Rubie C, Frick VO, Wagner M, Rau B, Weber C, Kruse B, Kempf K, Tilton B, König J, Schilling M: Enhanced expression and clinical significance of CC-chemokine MIP-3 alpha in hepatocellular carcinoma. Scand J Immunol 2006, 63:468-477.

21. Abiko Y, Nishimura M, Kusano K, Nakashima K, Okumura K, Arakawa T, Takuma T, Mizoguchi I, Kaku T: Expression of MIP-3alpha/CCL20, a macrophage inflammatory protein in oral squamous cell carcinoma. Arch Oral Biol 2003, 48:171-175.

22. Ghadjar P, Loddenkemper C, Coupland SE, Stroux A, Noutsias M, Thiel E, Christoph F, Miller K, Scheibenbogen C, Keilholz U: Chemokine receptor CCR6 expression level and aggressiveness of prostate cancer. J Cancer Res Clin Oncol 2008, 134:1181-1189.

23. UICC: TNM classification of malignant tumors. 5th edition. New York: Wiley-Liss; 1997

24. Bustin SA: Absolute quantification of mRNA using real time reverse transcription polymerase chain reaction assays. J Mol Endocrinol 2000, 25:169-193

25. Rubie C, Kempf K, Hans J, Su T, Tilton B, Georg T, Brittner B, Ludwig B, Schilling M: Housekeeping gene variability in normal and cancerous colorectal, pancreatic, esophageal, gastric and hepatic tissues. Mol Cell Probe 2005, 19:101-109.

26. Schoonjans F, Zalata A, Depuydt CE, Comhaire FH: MedCalc: a new computer program for medical statistics. Comp Meth Pro Biomed 1995 48:257-262.

27. Howes N, Neoptolemos JP: Risk of pancreatic ductal adenocarcinoma in chronic pancreatitis. Gut 2002, 51:765-766.

28. Lowenfels AB, Maisonneuve P, Cavallini G, Ammann RW, Lankisch PG, Andersen JR, Dimagno EP, Andren-Sandberg A, Domellof L: Pancreatitis and the risk for pancreatic cancer. N Engl J Med 1993, 328:1433-1437. 
29. Cook DN, Prosser DM, Forster R, Zhang J, Kuklin NA, Abbondanzo SJ, Niu XD, Chen SC, Manfra DJ, Wiekowski MT, Sullivan LM, Smith SR, Greenberg HB, Narula SK, Lipp M, Lira SA: CCR6 mediates dendritic cell localization, lymphocyte homeostasis, and immune responses in mucosal tissue. Immunity 2000, 12:495-503.

30. Lukacs NW, Prosser DM, Wiekowski M, Lira SA, Cook DN: Requirement for the chemokine receptor CCR6 in allergic pulmonary inflammation. $J$ Exp Med 2001, 194:551-555.

31. Dieu MC, Vanbervliet B, Vicari A, Bridon JM, Oldham E, Aït-Yahia S, Brière F, Zlotnik A, Lebecque S, Caux C: Selective recruitment of immature and mature dendritic cells by distinct chemokines expressed in different anatomic sites. J Exp Med 1998, 188:373-386.

32. Ekbom A, McLaughlin JK, Karlsson BM, Nyrén O, Gridley G, Adami HO, Fraumeni JF Jr: Pancreatitis and pancreatic cancer: a population-based study. J Natl Cancer Inst 1994, 86:625-627.

33. Karlson BM, Ekbom A, Josefsson S, McLaughlin JK, Fraumeni JF Jr, Nyrén O: The risk of pancreatic cancer following pancreatitis: an association due to confounding? Gastroenterology 1997, 113:587-592.

34. Giovannucci E, Michaud D: The role of obesity and related metabolic disturbances in cancers of the colon, prostate, and pancreas. Gastroenterology 2007, 132:2208-2225.

35. Rubie C, Oliveira V, Kempf K, Wagner M, Tilton B, Rau B, Kruse B, Konig J, Schilling M: Involvement of chemokine receptor CCR6 in colorectal cancer metastasis. Tumour Biol 2006, 27:166-174.

36. Matsui T, Akahoshi T, Namai R, Hashimoto A, Kurihara Y, Rana M, Nishimura A, Endo H, Kitasato H, Kawai S, Takagishi K, Kondo H: Selective recruitment of CCR6-expressing cells by increased production of MIP-3 alpha in rheumatoid arthritis. Clin Exp Immunol 2001, 125:155-161.

37. Shimizu Y, Murata H, Kashii Y, Hirano K, Kunitani H, Higuchi K, Watanabe A: CC-chemokine receptor 6 and its ligand macrophage inflammatory protein 3alpha might be involved in the amplification of local necroinflammatory response in the liver. Hepatology 2001, 34:311-319.

38. Homey B, Dieu-Nosjean MC, Wiesenborn A, Massacrier C, Pin JJ, Oldham E, Catron D, Buchanan ME, Müller A, deWaal Malefyt R, Deng G, Orozco R, Ruzicka T, Lehmann P, Lebecque S, Caux C, Zlotnik A: Up-regulation of macrophage inflammatory protein-3 alpha/CCL20 and CC chemokine receptor 6 in psoriasis. J Immunol 2000, 164:6621-6632.

doi: 10.1186/1479-5876-8-45

Cite this article as: Rubie et al., CCL20/CCR6 expression profile in pancreatic cancer Journal of Translational Medicine 2010, 8:45

Submit your next manuscript to BioMed Centra and take full advantage of:

- Convenient online submission

- Thorough peer review

- No space constraints or color figure charges

- Immediate publication on acceptance

- Inclusion in PubMed, CAS, Scopus and Google Scholar

- Research which is freely available for redistribution

Submit your manuscript at www.biomedcentral.com/submit
C Biomed Central 